\title{
The chlorophyll contents and growth performances of West Java (Indonesia) jobtears (Coix lacryma-jobi) accessions under low light intensity conditions
}

\author{
TITI JUHAETI", NINIK SETYOWATI ${ }^{\natural \bullet, ~ F A U Z I A ~ S Y A R I F ~}{ }^{\natural \bullet ~}$ \\ Botany Division, Research Center for Biology, Indonesian Institutes of Sciences. Jl. Raya Jakarta-Bogor Km 46, Cibinong, Bogor 16911, West Java, \\ Indonesia. Tel. +62-21-8765066, `email: juhaeti.KNG1980@ gmail.com, "vninik.setywangi@gmail.com, "vvfauziarohana@gmail.com
}

Manuscript received: 16 August 2020. Revision accepted: 15 October 2020.

\begin{abstract}
Juhaeti T, Setyowati N, Syarif F. 2020. The chlorophyll contents and growth performances of West Java (Indonesia) jobtears (Coix lacryma-jobi) accessions under low light intensity conditions. Biodiversitas 21: 5178-5185. The research was carried out to study the shading tolerance of five jobtears (Coix lacryma-jobi L) accession collected from Bandung, Kuningan, Garut, Sukabumi, and Sumedang West Java Indonesia. The existence of shade-tolerant jobtears was important to increasing its cultivation for food diversification effort. The research was conducted in the Botany Division, Research Center for Biology, Indonesian Institute of Sciences. The experimental design was a Randomized Complete Block Design with two factors. The first factors were $0 \%, 25 \%, 50 \%$, and $75 \%$ shading intensity. The second factors were five West Java jobtears accession, namely Bandung, Kuningan, Garut, Sukabumi, and Sumedang accession. The shading intensity set up artificially by the black plastic net. Jobtears seeds planted on planting beds on $70 x 100$ planting distance. The variable observed included microclimate, plant growth, leaf chlorophyll content, and grain production. The result indicated that jobtears accession showed differences in growth and production characters. Low light intensity significantly affected plant growth and production. The plant height, leaf number, and chlorophyll content variables increased until 50\% shading intensity and then decreased by $75 \%$ shading. Plant production decreased by the increased of shading intensity. The Bandung and Garut accessions can be determined as a potential low-light tolerant accession due to its better growth and production compared with others and the lowest percentage of decreased production. For further research, the Garut and Bandung accession can be used as a genetic biodiversity source for shading tolerance breeding efforts.
\end{abstract}

Keywords: Accession, growth, jobtears, production, shading

\section{INTRODUCTION}

Jobtears (Coix lacryma-jobi L.; Poaceae) is an important crop used as food and herbal medicine in Asian countries. A drug made of jobtears seed oil has been clinically applied to treat multiple cancers (Xi et al. 2016). Jobtears was also utilized as a medicinal plant (Badan POM RI, 2013). Jobtears is a highly nutritious minor cereal that has long been familiar and consumed by Indonesian people. Until now, jobtears can be found throughout Indonesia, although its use is very small (Handayani et al. 2019). There were various regional names for jobtears in Indonesia, such as Jali Watu, Japen, Jelen (Java), Anjalai, Jelai, Kenjeali, Perara, Senjeali (Sumatra) and Hajeli, Hanjeli, Hanjere in the Sunda area (Lim 2013). Now, its existence was excluded by major food (rice, maize, wheat flour) so it needs to re-introduce and repopularize. If proportionally major food crops (rice for example) are complemented by minor crops, this will not only increase the number of species but will also healthier because of more diverse food consumption (Christinck 2005). The development of cultivation and consumption of jobtears is not intended to replace rice as a staple food but to reduce dependence on major carbohydrate sources (rice, flour). In Philippine, jobtears was one of the options to search alternative staple crop that may substitute rice and corn (Aradilla 2018). The nutritional content of protein and fat jobtears was higher than rice and wheat. From 100 grams of edible seeds 10.1-15 g of water contained; protein 9.1$23.0 \mathrm{~g}$; fat from 0.5 to $6.1 \mathrm{~g}$; carbohydrates from 58.3 to 77.2 $\mathrm{g}$; fiber 0.3-8.4 g; ash 0.7-2.6 $\mathrm{g}$ with an energy of about 1500 $\mathrm{kJ} / 100 \mathrm{~g}$ (Grubben and Partohardjono 1996). The excellent nutritional profile and medicinal properties give reasons to further exploitation and utilization of jobtears as staple crops (Nehal et al. 2015).

As an effort to re-introduce and re-popularize jobtears as nutritional food, the "Hanjeli Tourism Village" in the area of Ciletuh Unesco Global Geopark Pelabuhan Ratu Sukabumi West Java was developed by the local community in Waluran Mandiri Village, Waluran District, Sukabumi Regency, West Java (under the leadership of Pak Asep). The " Hanjeli Tourism Village" attracts many visitors both from local and foreign tourists. The tourists can learn how to cultivate jobtears from planting to harvest, post-harvest until the process to create various tasted culinary based on grain and jobtears flour. It is known that various traditional (rice, porridge, tape, raginang, opak) and modern culinary (cookies, cakes) can be made from jobtears. Jobtears can also be used as a substitute for flour in making bread, to make bread can be used $70 \%$ wheat and $30 \%$ wheat flour (Lim 2013).

The Biology Research Center, Indonesian Institutes of Sciences, has been explored and collected jobtears from 
West Java Indonesia. Seven number of jobtears accession have been collected from Kuningan, Sumedang, Bandung, Sukabumi, and Garut district. Juhaeti (2016) indicated the differences in growth, production, the color of grain skin, and the nutritional value characters of those seven accessions. The Bandung accession showed the largest vegetative growth. The Bandung, Kuningan, and Sumedang accession had a brownish skin color, meanwhile, the Garut and Sukabumi were whitish. The grain of all accessions is known as free of gluten. The Sumedang accessions content a higher protein $(17.37 \%)$, vitamin B6 (27.63 mcg/100g), and vitamin B12 (3.6 mcg/100g) compared with others. The highest vitamin E content was on Garut accessions (174.41 $\mathrm{mg} / 100 \mathrm{~g})$.

There were no records regarded the production and trade of jobtears. As a minor plant, jobtears cultivated on a small scale on the agroforestry system in the yard or garden. Jobtears generally planted under young tree plants such as coffee and chocolate. As the canopy of tree plants bigger and larger, the light intensity under those trees stands decreases significantly. Jobtears is a shade-sensitive plant. In low light intensity environments, both jobtears growth and production were decreased significantly. The farmers lost their potential income due to they could not fulfill the demand. This limited domestic production suspected as the reason for the availability of imported jobtears in the market.

It is known that most cereal species and cultivar have been selected for full light conditions (Arenas-Corraliza et al. 2019). The research related to low light conditions to obtain shade-tolerant plants were still rare. Shade-tolerance is the relative capacity of the plant to compete for survival under shaded (less than optimal) conditions (Snyder 2010). Nowadays, jobtears research also predominantly by research on cultivation, nutritional content, and medicinal. As a minor crop, the extensification of jobtears cultivation suggested to marginal areas. One of them is the shading area on the yards, gardens, or in a state/private plantation. The potential of shading area under replanting stands on state/private plantations were quite large, reaching 12.1 million ha. Every year, around 3-4\% of the plantation area is a new plant (replanting), which can be used for the development of inter-cropped plants until the plantation is three years old (Sopandie and Kusumaningtyas 2011). The existence of shade-tolerant jobtears cultivar is required. So, the research on the growth and production of jobtears accession in shading conditions was an important step in the effort to obtain shade-tolerant cultivar. Therefore, this research was carried out to study the shading tolerance performance of seven jobtears accession from West Java as basic information for jobtears cultivation and breeding program.

\section{MATERIALS AND METHODS}

The study was conducted at the experimental garden facility in the Botany Division, Research Center for Biology, Cibinong, West Java, from May 2016 to November 2016.
The experiment was designed in a Randomized Complete Block Design (RCBD) with two factors. The first factor consisted of four levels of shading intensity, i.e., $0 \%, 25 \%$, $50 \%$, and $75 \%$. The second factor was composed of five jobtears accessions, namely Bandung, Kuningan, Garut, Sukabumi, and Sumedang. There were eight replications in every treatment.

The black plastic nets were applied to an artificial shading building for setting up $25 \%, 50 \%$, and $75 \%$ of shading intensity. The artificial shadings were made in the form of a simple rectangular building covering the plants from the soil surface. The height of the artificial building was 3 meters, the length was 6 meters, and the width was 6 meters. The jobtears seed was planted on planting bed by 70 $\mathrm{cm} \times 100 \mathrm{~cm}$ planting distance. On one week before planting, the $0.5 \mathrm{~kg}$ of manure and compost was added to the planting hole. Then, one day before planting, the 4 gr of NPK (16-1616) was added too. The number of plants used as biological replicates in this experiment was 4 shading $\times 5$ accession $\times 8$ replicates $=160$ plants

The plant observed variables included plant growth, chlorophyll content, and grain production. The grain harvesting was done when about $90 \%$ of panicles had matured, which was indicated by panicle becoming dry and brownish at 23 weeks after planting (WAP). The microclimate on shading building (including temperature, humidity, and light intensity), were observed daily at 09.00 am, $12.00 \mathrm{am}$, and $3.00 \mathrm{pm}$. The temperature and humidity measured using a Digital Thermohygrometer AS ONE TH321 (Corona), meanwhile the light intensity by lux meter (LUXOR). The chlorophyll content was measured by The Soil Plant Analysis Development (SPAD) chlorophyll meter Minolta Seri SPAD-502Plus.

Data obtained from the treatment were analyzed using SAS 9.1 software with a two-way analysis of variance (ANOVA) with a $5 \%$ level of confidence. If there was a significant effect between treatments, further significantly testing is done using the DMRT test at the level of $5 \%$.

\section{RESULTS AND DISCUSSION}

\section{Microclimate on artificial building}

The results of microclimate observations showed the differences in the $0 \%, 25 \%, 50 \%$, and $75 \%$ shade conditions. The light intensity was very different among artificial shading buildings. The light intensity decreased as the shade increased. The highest light intensity was obtained at $0 \%$ shading, while the lowest was at $75 \%$ shade. The temperature and humidity seemed not too different (Figure 1).

\section{Jobtears growth performances}

The growth performances observed consisted of plant height, number of leaves, number of tillers, and chlorophyll contents. Each variable discussed sequentially, starting from the single effect of plant accession, shading intensity, and interaction between accession and shade. 

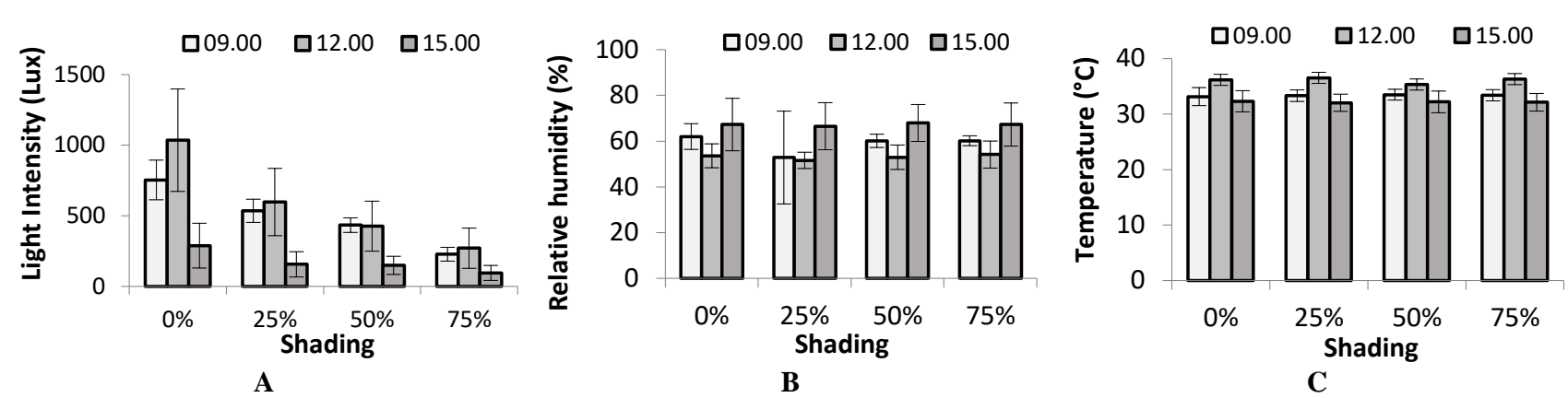

Figure 1. Microclimate on artificial shading building. A. Light intensity, B. Relative humidity, C. Temperature
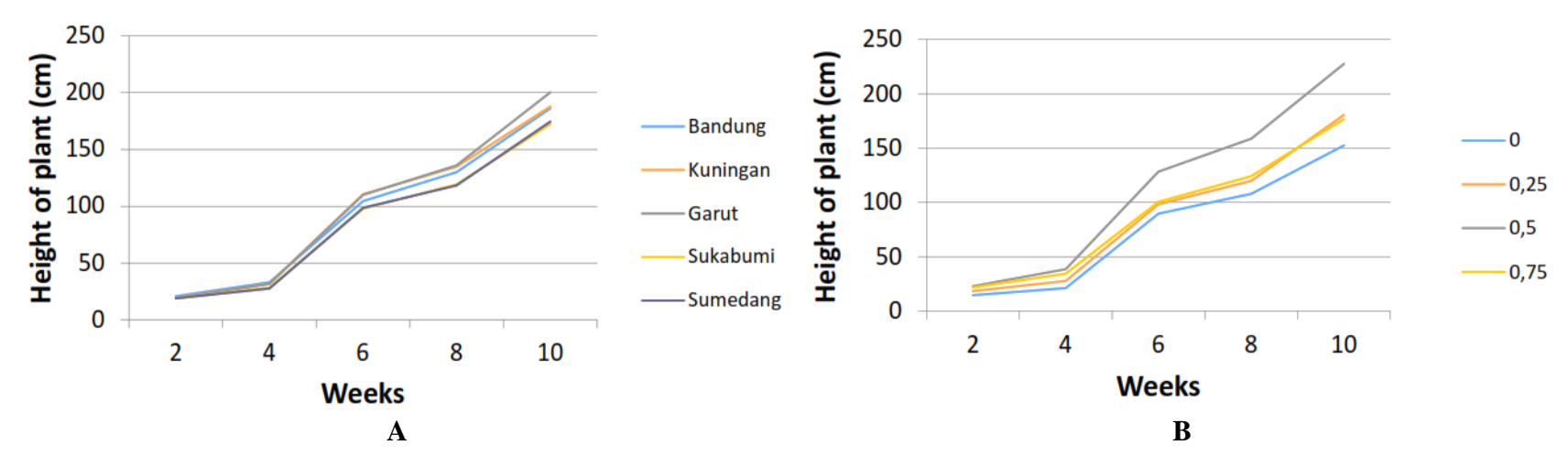

Figure 2. Growth performance of plant height on accessions (A) and shading (B) at 2-10 weeks after planting

\section{Plant height}

The plant height of jobtears accessions increased as an increase of plant age. At two weeks after planting (WAP), the plant height ranged from $18-20 \mathrm{~cm}$, not significantly different between accessions. The plant height showed a significantly different started from the age of 4 WAP (Figure 2.A) with values ranging from $27-33 \mathrm{~cm}$. At the age of six WAP, the plant height of Kuningan accessions was higher $(110.45 \mathrm{~cm})$ than other accessions. However, at the eight WAP, the height plant height was on Garut accession $(136.05 \mathrm{~cm})$. At the age of ten WAP, Garut accession still showed the highest plant height $(200,375 \mathrm{~cm})$, significantly different from other accessions (Table 1). The lowest plant height was on the Sukabumi accession $(172,425 \mathrm{~cm})$. The result of Juhaeti (2016) also showed the differences in plant height of those West Java jobtears accessions when planted in unshade conditions, and the tallest was on Garut accession.

The shade treatments were significantly affected plant height started from four 4 WAP (Table 2.B). The highest plant height obtained from $50 \%$ shading treatment, while the lowest was on $0 \%$ shading treatment (Figure 2.B). At the age of ten WAP, the height of jobtears planted on 50\% shading treatment reached $227.5 \mathrm{~cm}$ and is significantly different from other treatments. The lowest plant height was on $0 \%$ shading treatment $(152.4 \mathrm{~cm})$.

The two-way analysis of variance (ANOVA) with a $5 \%$ level of confidence showed that there is no interaction between accession and shading treatment. On plant height variables, each accession showed the same response to low light intensity conditions (Figure 3 ). The plant height from all accessions increased from 0\% shading until 50\% shading and then decreased by $75 \%$ shade.

\section{Number of leaves}

The plant accessions showed significantly different on the number of leaves variables started from two WAP (Figure 4.A). The Garut, Bandung, and Sukabumi accessions showed the highest number of leaves (2 pieces), and is significantly different from Kuningan (1.89), but not significantly different from Sumedang accessions (1.93). The Bandung accession at six and eight WAP showed the highest number of leaves than other accessions. In ten WAP, the Sukabumi showed the highest number of leaves (58.8 leaves), not significantly different from Kuningan accessions and Bandung accessions but significantly different from Garut and Sumedang accessions (Table 1). Juhaeti (2016) showed that Sukabumi accession produces the highest number of leaves when cultivated in unshade conditions.

Shading treatment showed a significant effect on number of leaves (Figure 4.B). The 50\% shading treatment produced the highest number of leaves, followed by $0 \%, 25 \%$, and $75 \%$. At the age of ten WAP (Table 2), the 50\% shading treatment showed the highest number of leaves (74.20) significantly different from others. The lowest number of leaves was $75 \%$ (21.32).

There was no interaction between accession and shading treatment to the number of leaves variables. However, the 
number of leaves of each accession generally increased from $0 \%$ until $50 \%$ shading intensity and then decreased by $75 \%$ shading. The Kuningan accession showed the highest number of leaves at $50 \%$ shade, followed by accessions from Sukabumi, Bandung, Sumedang, and Garut (Figure 5).

Table 1. The growth performance of jobtears accession at 10 weeks

\begin{tabular}{lccc}
\hline \multirow{2}{*}{ Accessions } & \multicolumn{3}{c}{ Growth performance at 10 weeks age } \\
\cline { 2 - 4 } & $\begin{array}{c}\text { Plant height } \\
\text { (cm) }\end{array}$ & $\begin{array}{c}\text { Number of leaves } \\
\text { (sheet) }\end{array}$ & $\begin{array}{c}\text { Number of } \\
\text { tillers }\end{array}$ \\
\hline Bandung & $186.25 \pm 33.98 \mathrm{~b}$ & $51.55 \pm 24.37 \mathrm{a}$ & $3.15 \pm 17.77 \mathrm{~b}$ \\
Kuningan & $187.80 \pm 29.56 \mathrm{~b}$ & $55.65 \pm 30.32 \mathrm{a}$ & $3.25 \pm 1.21 \mathrm{~b}$ \\
Garut & $\mathbf{2 0 0 . 3 6 \pm 3 2 . 4 2 a}$ & $38.75 \pm 21.42 \mathrm{~b}$ & $2.05 \pm 1.63 \mathrm{c}$ \\
Sukabumi & $172.43 \pm 32.24 \mathrm{c}$ & $\mathbf{5 8 . 8 0} \pm 29.59$ a & $\mathbf{4 . 2 5} \pm 2.84 \mathbf{a}$ \\
Sumedang & $174.53 \pm 33.36 \mathrm{c}$ & $39.55 \pm 23.24 \mathrm{~b}$ & $2.50 \pm 1.96 \mathrm{~cd}$ \\
\hline Note: $*$ ) The same letter in each column were not significantly \\
different based on Duncan's test of 5\%
\end{tabular}

different based on Duncan's test of $5 \%$

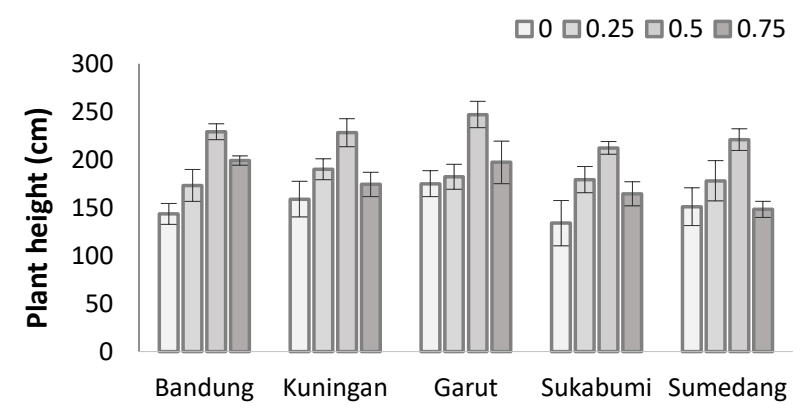

Jobtears accession

Figure 3. The plant height of accession on shade treatment at 10 weeks after planting
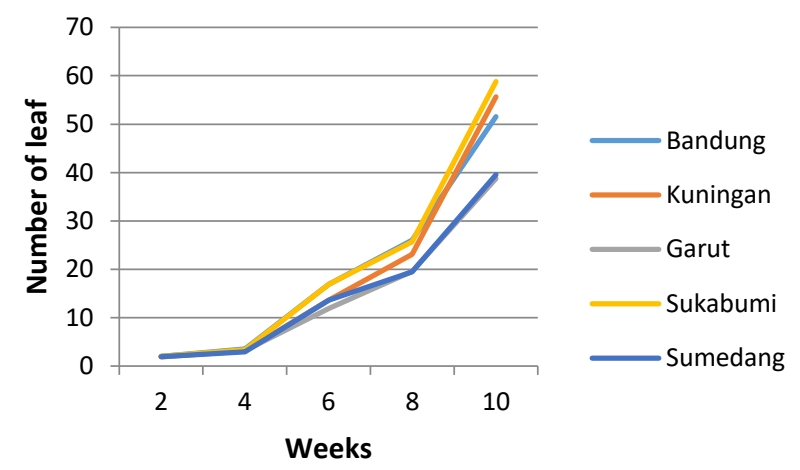

A
In general, there were no significant differences in the habitus of the Bandung, Kuningan, Garut, Sukabumi, and Sumedang accession, except for the color of the grain coat (Figure 6).

Table 2. The effect of shading treatments on growth performance at 10 weeks

\begin{tabular}{lccc}
\hline Shading & \multicolumn{3}{c}{ Growth performance at 10 weeks age } \\
\cline { 2 - 4 } & $\begin{array}{c}\text { Plant height } \\
(\mathbf{c m})\end{array}$ & $\begin{array}{c}\text { Number of leaves } \\
\text { (sheet) }\end{array}$ \\
\hline $0 \%$ & $152.44 \pm 21.67 \mathrm{c}$ & $55.96 \pm 17.37 \mathrm{~b}$ & $\mathbf{4 . 9 2 0} \pm 2.20 \mathrm{a}$ \\
$25 \%$ & $180.52 \pm 15.19 \mathrm{~b}$ & $43.96 \pm 21.02 \mathrm{c}$ & $3.24 \pm 1.78 \mathrm{~b}$ \\
$50 \%$ & $\mathbf{2 2 7 . 5 0} \pm \mathbf{1 5 . 6 4}$ a & $\mathbf{7 4 . 2 0} \pm 25.13 \mathrm{a}$ & $2.80 \pm 1.15 \mathrm{~b}$ \\
$75 \%$ & $176.62 \pm 23.34 \mathrm{~b}$ & $21.32 \pm 7.41 \mathrm{~d}$ & $1.20 \pm 1.00 \mathrm{c}$ \\
\hline Note: $*$ ) & The same letter in each column & was not significantly \\
different based on Duncan's test of $5 \%$.
\end{tabular}

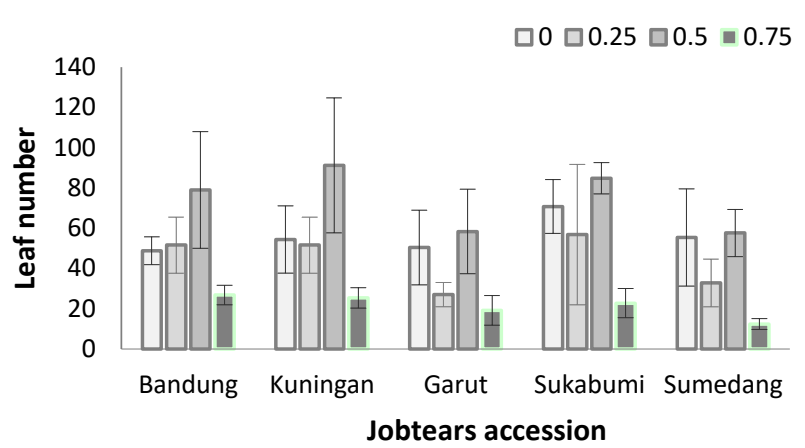

Figure 5. The number of leaves of accession on shading treatment at 10 weeks after planting

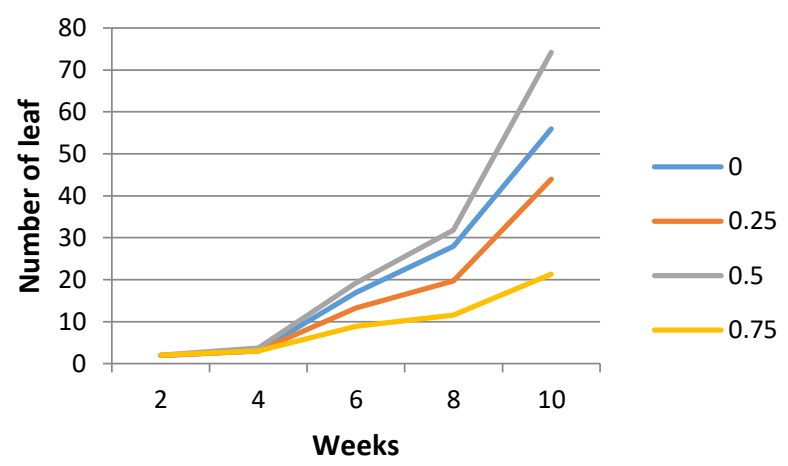

B

Figure 4. Growth performance of leaves number on accessions (A) and shading (B) at 2-10 weeks after planting 


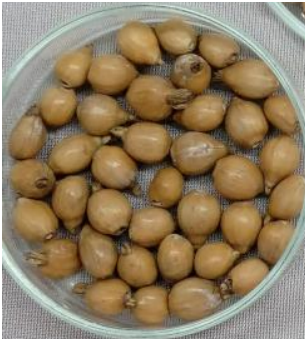

A

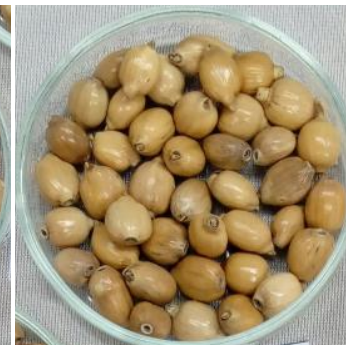

B

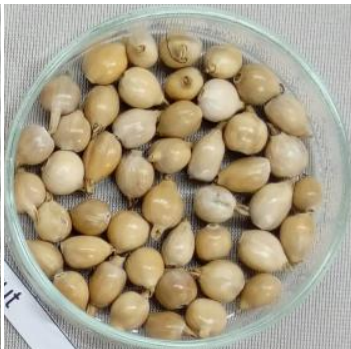

C

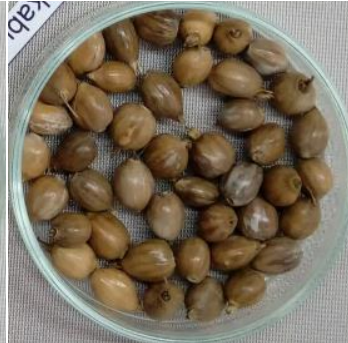

D

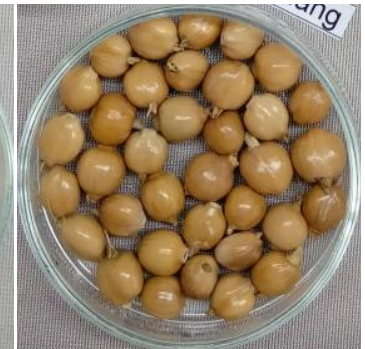

$\mathbf{E}$

Figure 6. Jobtears variation on color of grain coat. A. Bandung, B. Kuningan, C. Garut, D. Sukabumi, E. Sumedang

\section{Number of tillers}

Tiller is a lateral shoot from the base of the stem, especially in grass or cereal. The jobtears accession showed the differences in its ability to produced a tiller. The tillers started to grow at six WAP (Figure 7.A). Along the observation periods, the largest number of tillers was on the Sukabumi accession. This result was consistent with Juhaeti (2016), which showed the Sukabumi accession produces the highest number of tillers in its cultivation in shadeless conditions. Meanwhile, the lowest was on the Garut. At ten WAP, the Sukabumi accession has produced the highest number of tillers (4.25) significantly different from others. The lowest was on the Garut accession (Table 1).

Shading treatment significantly affected the number of the tiller variable. The tiller began to appear at six WAP. The jobtears planted on $0 \%$ shading intensity produced the largest number of tillers. The tiller numbers decreased by increased light intensity (Figure 7.B). On ten WAP, job tears planted on $0 \%$ shading intensity produced the highest number of tillers (4.92), and the lowest was at $75 \%(1.20)$ (Table 2).

\section{Growth performance of each accession under shading treatment}

The interaction effect between accession and shading treatments were not significantly different on all variable observed. The number of tiller of all the jobtears accession decreased by increased shading intensity (Figure 8). The highest number of tillers reached on the Sukabumi accession in $0 \%$ shading treatment. Meanwhile, the lowest was on Sumedang accession on $75 \%$ shading intensity. Although the Sukabumi accession showed the highest number of the tiller on $0 \%$ shading, unfortunately, its ability decreased drastically by the higher shading intensity. The smallest reduction of the number of tillers was on the Kuningan accession.

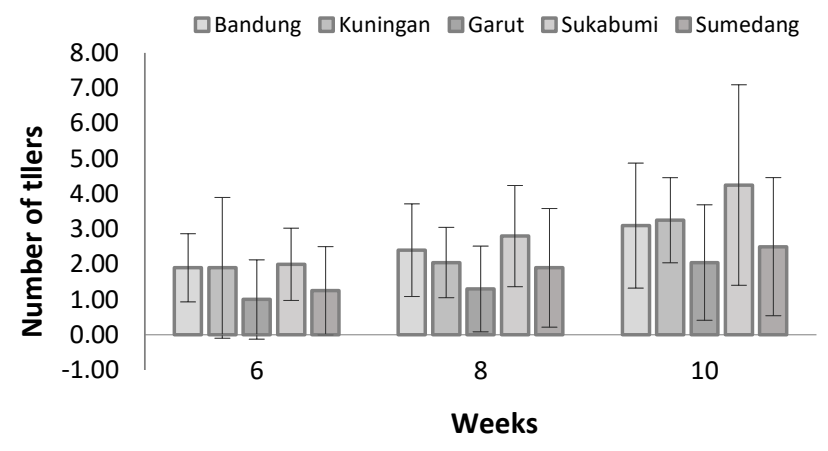

A

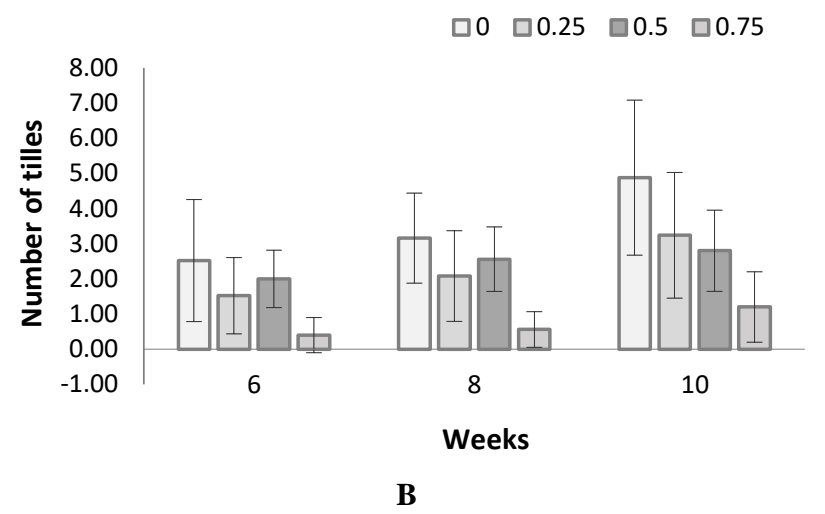

Figure 7. Growth performance of tillers number on accessions (A) and shading (B) at 6-10 weeks after planting

Table 3. The response of shading treatment to chlorophyll content on 8 WAP

\begin{tabular}{lc}
\hline Shading (\%) & Chlrophyll content (SPAD) \\
\hline 0 & $51.54 \pm 2.59 \mathrm{~b}$ \\
25 & $51.66 \pm 3.03 \mathrm{~b}$ \\
50 & $53.57 \pm 2.66 \mathrm{a}$ \\
75 & $48.88 \pm 2.86 \mathrm{c}$ \\
\hline
\end{tabular}

Note: The same letter in the same column indicated no significant difference at $5 \%$ Duncan test
Table 4. The response of jobtears accession to chlorophyll content on 8 WAP

\begin{tabular}{lc}
\hline Accession & Chlorophyll content (SPAD) \\
\hline Bandung & $53.76 \pm 1.98 \mathrm{a}$ \\
Kuningan & $51.69 \pm 3.79 \mathrm{~b}$ \\
Garut & $50.42 \pm 2.88 \mathrm{bc}$ \\
Sukabumi & $51.56 \pm 2.45 \mathrm{~b}$ \\
Sumedang & $49.54 \pm 3.19 \mathrm{c}$ \\
\hline
\end{tabular}

Note: The same letter in the same column indicated no significant difference at $5 \%$ Duncan test 


\section{Chlorophyll content}

The leaf chlorophyll content was measured at the age of 8 WAP on the fully opened leaf, located on 3rd leaf from the shoot tip. The chlorophyll content was significantly affected by shading treatment. Until $50 \%$ shading, the chlorophyll content was increased and then decreased by $75 \%$ shading. The 50\% shading showed the highest chlorophyll content (53.57 SPAD), and it was significantly different from others. The lowest chlorophyll content was on $75 \%$ shading (Table $3)$. The decrease in the total chlorophyll content of jobtears leaves planted in shaded conditions was as same as Setaria plants (Ridwan et. al. 2018).

The chlorophyll content was significantly different among the jobtears accessions. The Bandung accession showed the highest chlorophyll content significantly different from others. Meanwhile, the Sumedang accession showed the lowest chlorophyll content (Table 4).

The observation result showed that there was no interaction between shade and accession on chlorophyll content. However, in general, it appears that the chlorophyll content of each accession increases to $50 \%$ shade then decreases at $75 \%$ shade (Figure 9).

\section{Production performance}

The jobtears accession showed significantly different in grain production variables (Figure 10.A). The Bandung accession showed the highest grain production, and significantly different from others. The grain production of Kuningan, Garut, and Sukabumi was not significantly different, and lower than Bandung. Meanwhile, Kuningan $(91.66 \mathrm{~g})$ and Garut $(91.18 \mathrm{~g})$ showed the lowest grain production.

Shade treatment significantly affected grain production (Figure 10.B). Seed production decreases with increasing shade. The highest seed production obtained at $0 \%$ shade was significantly different from other treatments. The $75 \%$ treatment resulted in the lowest seed production.

The flowering behavior of each accession in each shade treatment showed differently. The jobtears accession started to initiate the flower at the age of $9 \mathrm{WAP}$ at $50 \%$ shade. On ten weeks after planting (Figure 11), all of the accession planted on $50 \%$ shading intensity started to flowering, followed by $25 \%, 0 \%$. The latest was on $75 \%$ shading intensity. The Kuningan accessions planted on 50\% shading showed the fastest flowering time. Under unfavorable conditions, growth duration of jobtears extended by two to three months (Aradilla 2018). Shading stress delays flowering and decreases biomass and grain yield. The grain yield of foxtail millet reduced by 61 percent with increasing shading intensity contrasting with no shading (Parande et al. 2019).

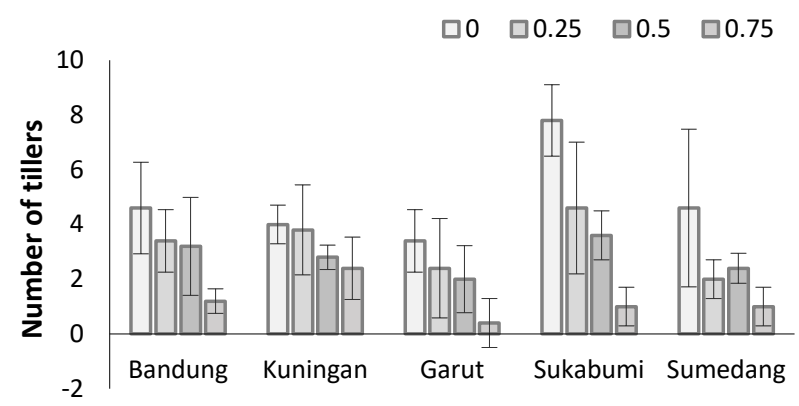

Jobtears accession

Figure 8. The number of tiller of each jobtears accession on shading treatments on 10 weeks after planting

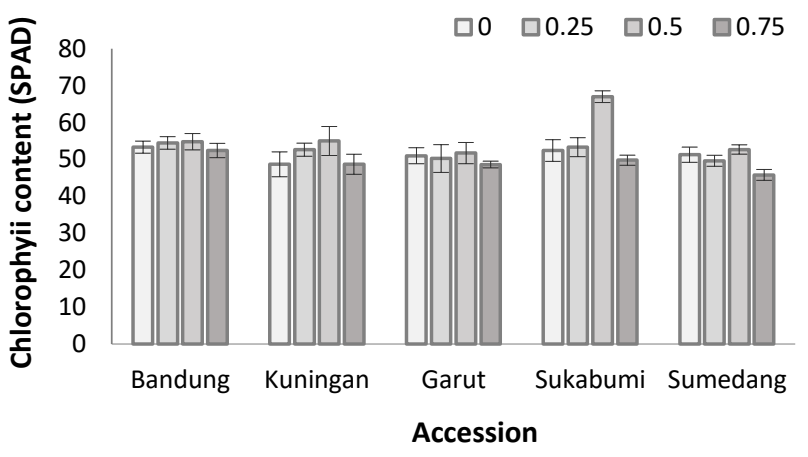

Figure 9. Leaf chlorophyll of each accession on shading treatment at 8 weeks after planting

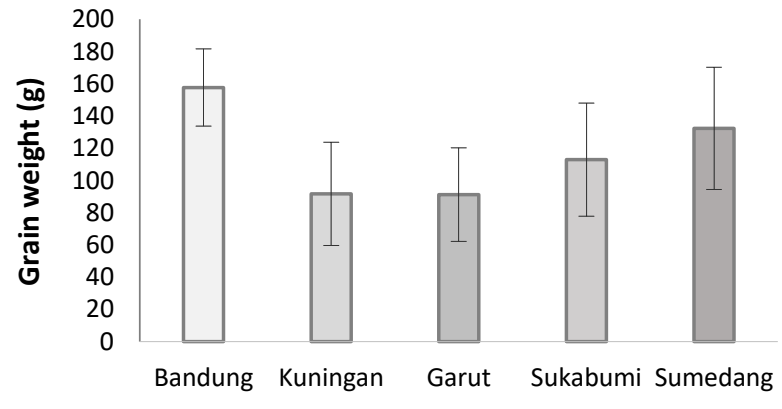

Accession

A

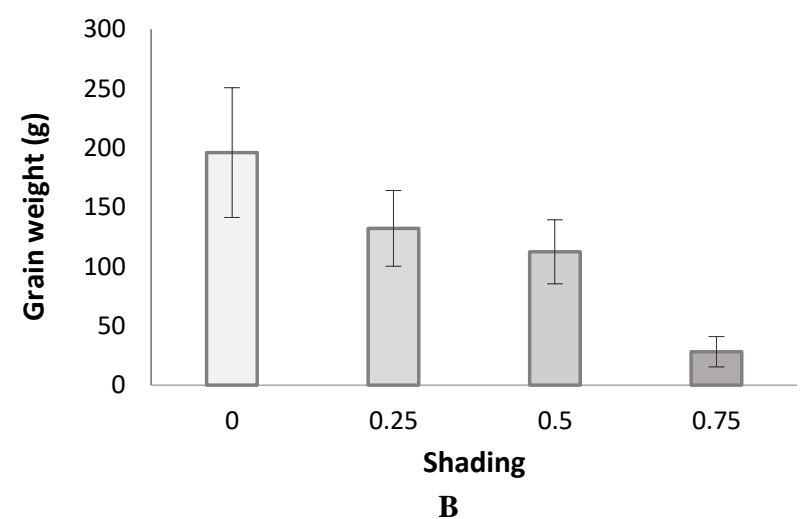

B

Figure 10. The main effect of accession (A) and shading (B) on production performance at 23 weeks after planting 


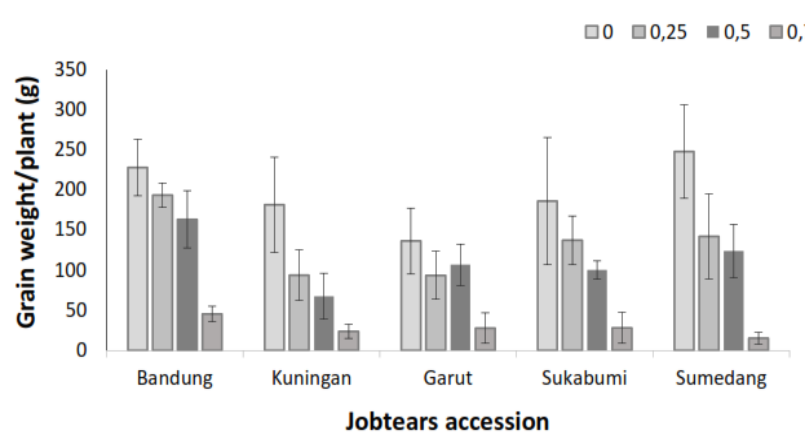

Figure 11. Flowering percentage of each accession by shading intensity on 10 weeks after planting

Table 5. Decreased percentages of grain production of each accession and shading intensity

\begin{tabular}{lllcl}
\hline Accession & $\mathbf{0 \%}$ & \multicolumn{1}{c}{$\mathbf{2 5 \%}$} & \multicolumn{1}{c}{$\mathbf{5 0 \%}$} & \multicolumn{1}{c}{$\mathbf{7 5 \%}$} \\
\hline Bandung & 0 & $\mathbf{1 5 . 1} \pm 12.15$ & $28.3 \pm 18.93$ & $80.00 \pm 4.6$ \\
Kuningan & 0 & $48.3 \pm 3.85$ & $62.8 \pm 16.86$ & $86.9 \pm 10.17$ \\
Garut & 0 & $\mathbf{3 1 . 3} \pm 14.77$ & $\mathbf{2 1 . 7} \pm 16.32$ & $79.5 \pm 14.58$ \\
Sukabumi & 0 & $24.4 \pm 18.98$ & $44.8 \pm 18.04$ & $84.5 \pm 17.92$ \\
Sumedang & 0 & $42.6 \pm 17$ & $50 \pm 15.25$ & $93.9 \pm 4.12$ \\
\hline
\end{tabular}

The observation result (Figure 12) indicated that grain production of all accessions decreased with the increase of shade intensity. In $0 \%$ shade, Sumedang accession shows the highest production, as same as Juhaeti (2016), followed by Bandung, Kuningan, Sukabumi, and Garut. In 25\% and $50 \%$, the highest production was in Bandung accessions. The result showed that the growth and yield of Setaria italica were decreased by the increase of shading (Ridwan et al. 2018).

The grain production of all accession was decreased due to low light intensity in the environment (Table 5). In $25 \%$ shade conditions, the Kuningan and Sumedang showed the highest decline of grain production (48.3\% and 42.6\%). Meanwhile, at 50\% shade, the Bandung and Garut showed the smallest reduction (28.3\% and $21.7 \%)$. At $75 \%$ shade, all accessions have shown a decline in the production of more than $50 \%$.

\section{Discussion}

Jobtears is a C4 plant (Handayani et al. 2019). The others were sorghum (Sorghum bicolor), pearl millet (Pennisetum glaucum), proso millet (Panicum miliaceum), finger millet (Eleusine coracana), and amaranth (Sage and $\mathrm{Zu} 2011$ ). The decreased growth and production of jobtears planted in low light conditions have also occurred in other C4 plants, such as sorghum. Sorghum has recommended to cultivate in the early stage of an agroforestry area (0-25\% shading) and not recommended in the middle $(25-50 \%)$ and advanced stage (more than $75 \%$ ). It is due to the low intensity of solar radiation that reaches the land surfaces of middle and advanced agroforestry areas were decline significantly the growth and biomass production of sorghum cultivars

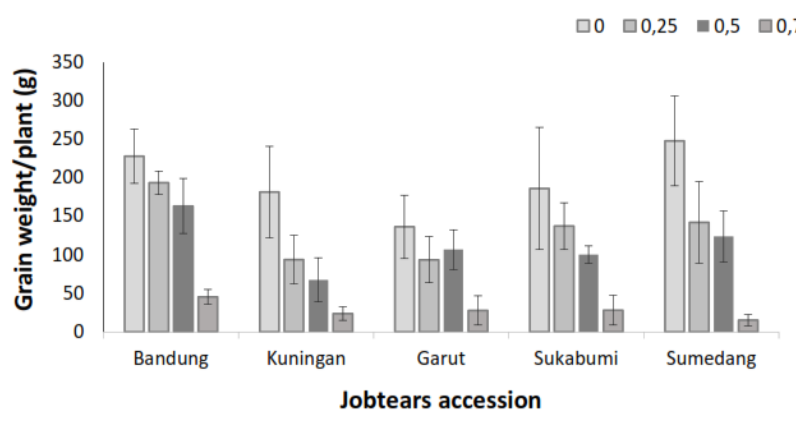

Figure 12. Grain production of each accession and shading intensity on 23 WAP

(Novitasari et al. 2016). The leaf characteristics of C4 crops usually have higher radiation, water and nitrogen use efficiencies compared to the $\mathrm{C}_{3}$ species (Zehong et al. 2015). Nerea et al. (2013) showed that species C4 (Zea mays, Miscanthus $x$ giganteus, and Flaveria bidentis are able to optimize photosynthesis over arange of PARs, including low light.

The observation indicated that the growth and production of jobtears cultivated under low light intensity were decreased. It was known that jobtears is a $\mathrm{C} 4$ plant that has photosynthesis high energy costs and low plasticity compared with C3 in low light environments (Balasaheb et al. 2018). As a comparison, the foxtail millet showed that low light penetration on its canopy reduced photosynthesis and plant yield (Nandini and Shridhara 2019). Biomass accumulation is dependent on radiation use efficiency and light interception (Sankalpi and Thomas 2014). The shading intensity caused a reduction of the light intensity required for photosynthesis, resulting in a decrease of assimilation products (Lambers and Hendriks 1992). Finally, it can be decreased plant biomass dry weight (Ginting et al. 2015). Under normal conditions, plants will allocate energy and nutrient for their growth and production. But, under stress conditions, plants will use much more energy and nutrient for their survival (Prasch and Uwe 2015). Yuan et al. (2017) showed that on foxtail millet the grain fresh mass per panicle, yield, photosynthetic pigment contents, net photosynthetic rate, stomatal conductance, effective quantum yield of PSII photochemistry, and electron transport rate decreased with the increase of shading intensity. Shading also changed a double-peak diurnal variation of photosynthesis to a one-peak curve. The lower yield of foxtail millet was caused mainly by a reduction of grain mass assimilated, a decline in chlorophyll content, and a low photosynthetic rate due to low light during the grainfilling stage. Reduced light energy absorption and conversion, restricted electron transfer, and reduced stomatal conductance might cause a decrease in photosynthesis.

The study indicated that there were differences in growth and production performances among jobtears accession. The shading intensity was significantly affected plant growth and production. The plant production decreased by the increase 
of shading intensity. The Bandung and Garut accessions can be determined as a potential low-light tolerant accession for its better growth, production, and the lowest percentage of decreased grain production when it planted on low light intensity conditions. For further utilization, Garut and Bandung accession can be used as a genetic resource for the shading tolerance breeding program.

\section{ACKNOWLEDGEMENTS}

The author gratefully thanks Plant Bio-Prospecting Project of Research Center for Biology, Indonesian Institutes of Sciences, Bogor, Indonesia for funding this research. The author also would like to thank Indra Gunawan for helping us during the research period. The author has an equal contribution to this work.

\section{REFERENCES}

Aradilla AR. 2018. Phenology, growth and yield performance of adlay (Coix lacryma-jobi L.) grown in adverse climatic conditions. Int J Res Rev 5 (3): 16-24.

Arenas-Corraliza MG, Rolo V, López-Díaz ML. 2019. Wheat and barley can increase grain yield in shade through acclimation of physiological and morphological traits in Mediterranean conditions. Sci Rep 9 (1): 1 10.

Badan POM RI. 2013. The latest scientific data series for jobtears (Coix lacryma-jobi L.) as medicinal plants. Direktorat Obat Asli Indonesia Deputi II, Badan Pengawas Obat dan Makanan RI. [Indonesian]

Balasaheb VS, Robert ES, Oula G. 2018. Shade compromises the photosynthetic efficiency of NADP-ME less than that of PEP-CK and NAD-ME $\mathrm{C}_{4}$ grasses. J Exp Bot 69 (12): 3053-3068.

Christinck. 2005. Underutilized species-rich potential is being wasted. In Lossau A, Li (eds) Sources Book on Sustainable Agrobiodiversity Management. Social Science Academic Press, PR China.

Ginting J, Damanik BSJ, Jamuda MS, Chairul M. 2015. Effect of shade, organic materials and varieties on growth and production of upland rice. Int J Sci Technol Res 6 (1): 68-74.

Grubben GJH, Partohardjono S (eds) 1996. Cereals. Plant Resources of South East Asia. No. 10. Backhuys Publ Leiden.

Handayani F, Sumarmiyati, Rahayu SP. 2019. Morphological characteristic of local accessions job's tears (Coix lacryma-jobi) of East Kalimantan Pros Sem Nas Masy Biodiv Indon 5 (2): 228-233. [Indonesian]
Juhaeti T. 2016. Growth, production and nutrition value of jobtears (Coix lacryma-jobi L.) accession from West Java. Proceedings of Semabio UIN Bandung, Bandung. [Indonesian]

Lambers H, Hendrik P. 1992. Inherent variation in growth rate between higher plants: A search for physiological causes and ecological consequences. Adv Ecol Res 23, 187-261.

Lim TK. 2013. Edible Medicinal and Non Medicinal Plant. Springer, Nederlland. DOI 10.1007/978-007-5653-3_14

Nandini KM, Sridhara S. 2019. Response of growth yield and quality parameters of foxtail millet genotypes to different planting density. Intl J Curr Microbiol App Sci 8 (2): 1765-1773.

Nehal N, Sonia M, Rajinder KG. 2015. Two promising under-utilized grains: A Review. Indian J Tradit Knowledge 14 (3): 416-422.

Nerea U, Wei S, David MK, Asaph BC. 2013. The efficiency of C4 photosynthesis under low light conditions in Zea mays, Miscanthus $\mathrm{x}$ giganteus and Flaveria bidentis. Plant Cell Environ 36: 365-381.

Novitasari PY, Putra ETS, Rogomulyo R. 2016. The growth and biomass production of three sorghum cultivars (Sorghum bicolor L. Moench ) under three stages of agroforestry at Gunungkidul Regency. Vegetalika 5 (3): 53-62. [Indonesian]

Parande S, Eslami SV, Jami Al-Ahmadi M. 2019. Effects of shading and nitrogen on phenology and yield of foxtail millet (Setaria italica L.) in competition with white pigweed (Amaranthus albus L.). agris.fao.org. https://agris.fao.org/agris-search/search.do?recordID=IR2019700074.

Prasch CM, Uwe S. 2015. Signaling events in plants: Stress factors in combination change the picture. Environ Exp Bot 114: 4-14.

Ridwan, Handayani T, Witjaksono. 2018. Response of millet (Setaria italica (L.) P. Beauv) to low light condition. Jurnal Biologi Indonesia 14 (1): 23-32. [Indonesian]

Sage RF, Zhu XG. 2011. Exploiting the engine of C4 photosynthesis. J Exp Bot 62 (9): 2989-3000.

Sankalpi NW, Thomas PB. 2014. Enhancing the productivity of grasses under high-density planting by engineering light responses: from model system to feedstocks. J Exp Bot 65 (11): 2825-2834.

Snyder M. 2010. What is shade tolerance and why is it so important? https://northernwoodlands.org/articles/article/what-is-shadetolerance-and-why-is-it-so-important].

Sopandie D, Trikoesoemaningtyas. 2011. Intercropping development under annual plant stands. Iptek Tanaman Pangan 6: 168-182. [Indonesian]

Xi XJ, Zhu YG, Tong YP, Yang XL, Tang NN, Ma SM. 2016. Assessment of the genetic diversity of different job's tears (Coix lacryma-jobi L.) accessions and the active composition and anticancer effect of its seed oil. PLoS ONE 11 (4): e0153269. DOI:10.1371/journal. pone.0153269

Yuan XY, Zhang LG, Huang L, Qi X, Wen YY, Dong SQ, Song XE, Wang HF, Guo PY. 2017. Photosynthetic and physiological responses of foxtail millet (Setaria italica $\mathrm{L}$.) to low-light stress during grain-filling stage. Photosynthetica 55 (3): 491-500.

Zehong D, Sarit W, Minghui W, Baijuan D, Lei H, Lin W, Xiaoyu T, Silin Z, Christopher M, Thomas PB, Qi S, Pinghua L. 2015. Identification of photosynthesis-associated $\mathrm{C} 4$ candidate genes through comparative leaf gradient transcriptome in multiple lineages of $\mathrm{C} 3$ and $\mathrm{C} 4$ species. PLoS One 10 (10): e0140629. DOI: 10.1371/journal.pone.0140629. 